\title{
Celebrating 40 years anaerobic sludge bed reactors for industrial wastewater treatment
}

\author{
J. B. van Lier - F. P. van der Zee • \\ C. T. M. J. Frijters • M. E. Ersahin
}

Published online: 30 August 2015

(C) The Author(s) 2015. This article is published with open access at Springerlink.com

\begin{abstract}
In the last 40 years, anaerobic sludge bed reactor technology evolved from localized lab-scale trials to worldwide successful implementations at a variety of industries. High-rate sludge bed reactors are characterized by a very small foot print and high applicable volumetric loading rates. Best performances are obtained when the sludge bed consists of highly active and well settleable granular sludge. Sludge granulation provides a rich microbial diversity, high biomass concentration, high solids retention time, good settling characteristics, reduction in both
\end{abstract}

J. B. van Lier $(\square) \cdot$ M. E. Ersahin

Sanitary Engineering Section, Department of

Watermanagement, Faculty of Civil Engineering and

Geosciences, Delft University of Technology, Stevinweg

1, 2628 CN Delft, The Netherlands

e-mail: j.b.vanlier@tudelft.nl

J. B. van Lier

Unesco - IHE, PO Box 3015, 2601 DA Delft

The Netherlands

F. P. van der Zee

Biothane Systems International, Tanthofdreef 21,

2600 GB Delft, The Netherlands

C. T. M. J. Frijters

Paques BV, T. de Boerstraat 24, 8561 EL Balk

The Netherlands

M. E. Ersahin

Environmental Engineering Department, Civil

Engineering Faculty, Istanbul Technical University,

34469 Maslak, Istanbul, Turkey the operation costs and reactor volume, and high tolerance to inhibitors and temperature changes. However, sludge granulation cannot be guaranteed on every type of industrial wastewater. Especially in the last two decades, various types of high-rate anaerobic reactor configurations have been developed that are less dependent on the presence of granular sludge, and many of them are currently successfully applied for the treatment of various kinds of industrial wastewaters worldwide. This study discusses the evolution of anaerobic sludge bed technology for the treatment of industrial wastewaters in the last four decades, focusing on granular sludge bed systems.

Keywords Anaerobic biotechnology · Granulation · Flocculent sludge · High-rate reactor technology • Industrial wastewater treatment $\cdot$ Sludge bed reactors

\section{Introduction}

As an energy generating process, the anaerobic treatment technology has been receiving growing interest since its first application; primarily due to the simplicity of the technology, low space requirement, low excess sludge production and the positive energy balance in comparison to the conventional aerobic treatment technologies (van Lier 2008). Notably, by using anaerobic treatment instead of activated sludge about $1 \mathrm{kWh}$ (fossil energy) $\mathrm{kg}^{-1} \mathrm{COD}$ removed is saved, depending on the system which is used for 
aeration of activated sludge. Moreover, under anaerobic conditions, the organic matter is converted in the gaseous energy carrier $\mathrm{CH}_{4}$, producing about $13.5 \mathrm{MJ}$ $\mathrm{CH}_{4}$ energy kg ${ }^{-1} \mathrm{COD}$ removed, giving $1.5 \mathrm{kWh}-$ electric (assuming $40 \%$ electric conversion efficiency). In countries like the Netherlands, the over $90 \%$ reduction in sludge production significantly contributed to the economics of the plant, whereas the high loading capacities of anaerobic high-rate reactors allowed for $90 \%$ reduction in space requirement, both compared to conventional activated sludge systems. These striking advantages lead to the rapid development of anaerobic high-rate technology for industrial wastewater treatment. In this development, the group of prof. Gatze Lettinga at Wageningen University, in close cooperation with the contractors Paques BV and Biothane Systems International played a crucial role as recently outlined by Lettinga (2014). Anaerobic high-rate technology has improved significantly in the last few decades with the applications of differently configured high-rate reactors, especially for the treatment of industrial wastewaters.

The relatively rapid implementation of high-rate anaerobic treatment coincided with the implementation of the new environmental laws in Western Europe and the co-occurrence of very high energy prices in the 1970s. High amounts of highly concentrated wastewaters from food processing and beverages industries, distilleries, pharmaceutical industries, and pulp and paper mills, suddenly required treatment. The first anaerobic full scale installations confirmed that while treating the effluents, considerable amounts of useful energy in the form of biogas could be obtained for possible use in the production process (van Lier 2008; Ersahin et al. 2011). As mentioned, the extremely low excess sludge production, was another very important asset of high-rate anaerobic treatment systems. And interestingly, the production of granular sludge, even gave a market value to excess sludge, since granular sludge is nowadays sold on the market for reinoculating or starting up new reactor systems. From the 1970's onwards, high-rate anaerobic treatment is particularly applied to organically polluted industrial wastewaters, coming from the agro-food sector and the beverage industries (Table 1). Currently, in more than $90 \%$ of these applications, anaerobic sludge bed technology is applied, for which the presence of granular sludge is of eminent importance. Interestingly, both the number of anaerobic reactors installed, as well the application potential of anaerobic wastewater treatment is rapidly expanding. Authors estimate that the current number of installed anaerobic highrate reactors exceed the 4000 , whereas nowadays wastewaters are treated that were previously not considered for anaerobic treatment, such as chemical wastewaters containing toxic compounds or wastewaters with a complex composition. For the more extreme type of wastewaters novel high rate reactor system have been developed as is discussed below.

This paper presents a comprehensive evaluation of anaerobic sludge bed technology for the treatment of industrial wastewaters with a focus on different types of high-rate reactors developed in the last 40 years.

\section{Development of high-rate anaerobic reactor technology}

Many different reactor configurations have been used and are used for the anaerobic treatment of wastewaters, as reviewed by McCarty (2001). One of the first continuous flow anaerobic reactors was designed in 1905 by Karl Imhoff, who developed a single flowthrough tank for enhanced settling and concomitant digestion of the settled solids. The innovative Imhoff tank was particularly applied for municipal wastewaters and is still functional in various parts of the world, particularly in warm climate regions (Imhoff 1916). Anaerobic treatment of industrial wastewaters was for the first time seriously investigated by Arthur M. Buswell et al. (Buswell 1957; Buswell et al. 1932) starting from the 1920s. In fact, Buswell unravelled the biochemical oxidation-reduction reactions occurring during anaerobic digestion (Buswell and Sollo 1948), thus advancing the basic process understanding enormously. By using Buswell's formula one can easily calculate the expected methane generation from known biochemical compounds. In their reactor studies, they made use of completely mixed systems in which the hydraulic retention time (HRT) was similar to the solids retention time (SRT). In such systems, the anaerobic conversion capacity is fully linked to the growth rate of bacteria. Since these growth rates are very low, reactor systems are very large. Completely stirred tank reactor (CSTR) designs were the predominant systems used for anaerobic treatment until the 1960s. The most striking disadvantage of these lowrate anaerobic reactors is the requirement of large 
Table 1 Application of anaerobic technology to industrial wastewater (Total number of registered installed reactors $=2266$, census January 2007 (adopted from van Lier 2008))

\begin{tabular}{|c|c|c|}
\hline Industrial sector & Type of wastewater & $\begin{array}{l}\text { Installed reactors* (\% of } \\
\text { total) }\end{array}$ \\
\hline Agro-food industry & $\begin{array}{l}\text { Sugar, potato, starch, yeast, pectin, citric acid, cannery, confectionary, fruit, } \\
\text { vegetables, dairy, bakery }\end{array}$ & 36 \\
\hline Beverage & Beer, malting, soft drinks, wine, fruit juices, coffee & 29 \\
\hline Alcohol distillery & Can juice, cane molasses, beet molasses, grape wine, grain, fruit & 10 \\
\hline $\begin{array}{l}\text { Pulp and paper } \\
\text { industry }\end{array}$ & Recycle paper, mechanical pulp, NSSC, sulphite pulp, straw, bagasse & 11 \\
\hline Miscellaneous & $\begin{array}{l}\text { Chemical, pharmaceutical, sludge liquor, landfill leachate, acid mine water, } \\
\text { municipal sewage }\end{array}$ & 14 \\
\hline
\end{tabular}

* Various types of high-rate anaerobic reactor systems

reactor volumes in order to provide enough biomass concentration in the reactor (Rittmann and McCarty 2001; van Lier et al. 2008). By then it was clearly understood that any increase in treatment capacity can only be achieved by increasing the concentration of biocatalysts, i.e. the methanogenic sludge, in the anaerobic reactor. Therefore, the terminology 'highrate' reactors generally refers to systems in which the SRT is uncoupled from the HRT. With the introduction of high-rate reactors, the required reactor volumes and concomitant capital costs distinctly reduced, making anaerobic treatment of practical interest for cost-effective industrial wastewater treatment.

Anaerobic high-rate reactors can be classified by the way SRT is uncoupled from HRT. Immobilization of anaerobic sludge via granule and/or biofilm formation represents the traditional way to achieve the necessary biomass retention, enabling bioreactor operation at high biomass concentrations, and therefore at high volumetric loading rates (VLRs) (Lettinga et al. 1980; Rittmann and McCarty 2001). Besides, physical retention can also be used to achieve the essential sludge retention in situations where biofilm and granule formation does not proceed well. The latter is frequently the case when treating wastewaters with large amounts of suspended solids (SS) or when wastewaters are characterized by a high salinity and/or a high temperature. Physical retention can be achieved using a secondary clarifier with sludge return, similar to the activated sludge process, or by using a physical filtration barrier or a membrane.

Depending on the applied sludge retention mechanism, various high-rate anaerobic treatment configurations have been developed in the past four decades, such as the anaerobic contact process (ACP), anaerobic filter (AF), upflow anaerobic sludge blanket (UASB) reactor, fluidized bed (FB) reactor, expanded granular sludge bed (EGSB) reactor, internal circulation (IC) reactor, anaerobic baffled reactor (ABR), membrane coupled high-rate (UASB/EGSB/FB) reactors, and membrane coupled CSTR systems. The latter are better known as anaerobic membrane bioreactors (AnMBR). In addition, a number of variations in the basic designs have been proposed in the literature of which some made it to full scale application. Figure 1 shows various examples of high-rate anaerobic reactor configurations. At present, the high-rate sludge bed reactors, i.e. UASB and EGSB reactors and their derivatives, are most widely implemented for the anaerobic treatment of industrial wastewater, having about $90 \%$ of the market share of all installed systems (van Lier 2008). Their popularity for treating industrial wastewaters can be attributed to their compactness, ease of operation, while applying high VLRs at low HRTs (Rajeshwari et al. 2000; van Lier 2008). More recently, membrane coupled high-rate anaerobic reactor configurations are increasingly being researched, due to the large amount of comparable knowledge from aerobic MBR operations and the application niche which clearly exists for these systems (Dereli et al. 2012). Membrane assisted sludge retention ensures the accumulation of very slowly growing micro-organisms with inferior adherence properties, that are frequently needed for the anaerobic treatment of toxic and recalcitrant wastewaters. In this way, the aggregation property of the biomass loses its importance for substrate degradation capacity, and cell washout risk is non-existing. In 
Fig. 1 Examples of highrate anaerobic reactors: a ACP, b AF, c UASB reactor, d EGSB reactor, e membrane coupled CSTR reactor (AnMBR)

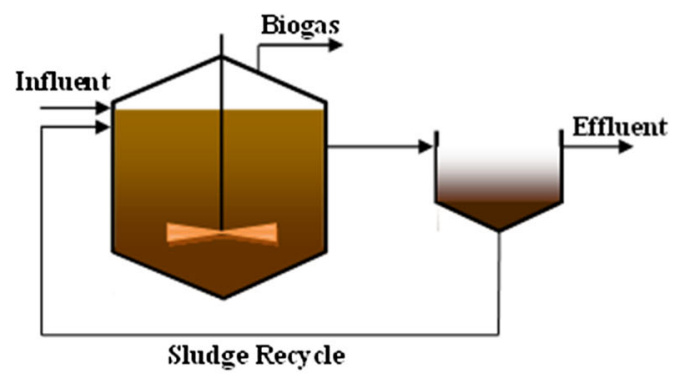

(a)

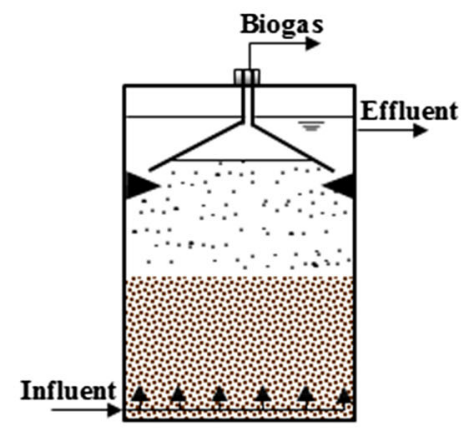

(c)

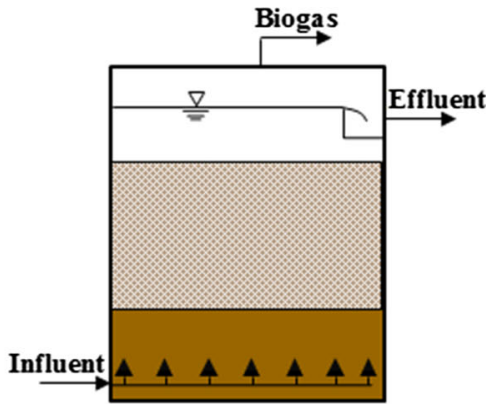

(b)

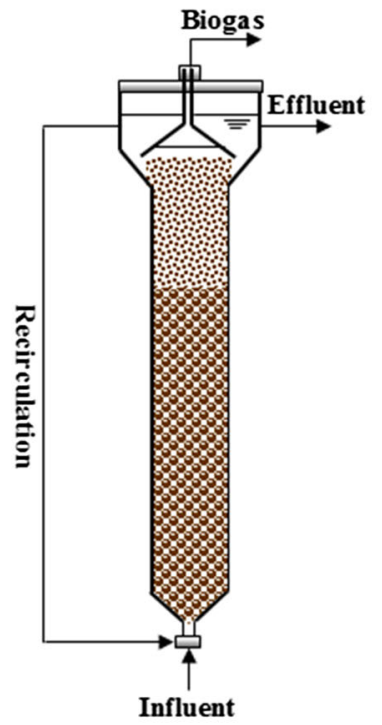

(d)

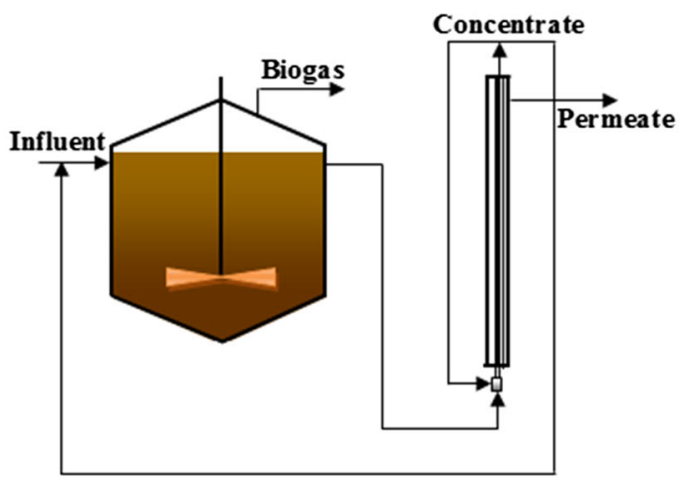

(e)

addition, membrane coupled systems offer a costeffective alternative to produce nutrient rich and solids free effluents; although not yet applied in practice, these effluents would be suitable for agricultural and landscaping irrigation (Ozgun et al. 2013, 2015).

\section{The first anaerobic high-rate reactors: ACP and $\mathrm{AF}$}

Following the historic development of high-rate reactors, the ACP process is the first configuration in 
which the SRT was uncoupled from the HRT. The reactor biomass concentration was increased by employing a secondary clarifier with return flow, similar to its aerobic homologue. The first ACP process was reported for the treatment of dilute packing house waste that has a COD of about $1300 \mathrm{mg} \mathrm{L}^{-1}$ (Schroepfer et al. 1955). The various versions of the first generation of these high-rate ACP systems for medium strength wastewaters were not very successful. In practice, the main difficulty was a poor separation of the active anaerobic sludge from the treated water in the secondary clarifier. Biogas formation and attachment in the settling tank were the other major problems (Rittmann and McCarty 2001). The poor sludge separation was attributed to the applied very intensive agitation in the bioreactor, creating very small sludge particles with a poor settleability. In addition, super-saturation of solubilized gases resulted in buoyant upward forces in the clarifier. The idea of the very intensified mixing was to ensure optimized contact between the sludge and the wastewater. Modern ACP systems apply much milder mixing conditions, whereas degasifying units are often equipped prior to secondary clarification. In fact, modern ACP systems are very effective for concentrated wastewaters with relatively high concentrations of SS. As such, ACP have a consolidated market share within the full scale applied anaerobic high-rate systems (van Lier 2008). Nonetheless, ACP effluents require a subsequent treatment step in order to comply with effluent restrictions.

An alternative way of sludge retention was found by applying inert support material into the bioreactor on which the anaerobic organisms can adhere. Whereas the earliest AF were already applied in the nineteenth century (McCarty 2001), the application for industrial wastewater treatment started in the 1960s in the US (Young and McCarty 1969; Young 1991). The AF, also called packed bed process, has been developed as a biofilm system in which biomass is retained based on (1) the attachment of a biofilm to the solid (stationary) carrier material, (2) entrapment of sludge particles between the interstices of the packing material, and (3) the sedimentation and formation of very well settling sludge aggregates. AF technology can be applied in upflow and downflow reactors (Young and Yang 1989). Various types of synthetic packing materials, as well as natural packing materials, such as gravel, coke and bamboo segments, have been investigated in order to be used in AFs. Research results indicated that the shape, size, weight, specific surface area, and porosity of the packing material are important aspects. Also the surface adherence properties with regard to bacterial attachment are important. Applying proper support material, AF systems can be rapidly started, owing to the efficient adherence of anaerobic organisms to the inert carrier. The ease of starting up the AFs was the main reason for its popularity in the eighties and nineties. Problems with AF systems generally occur during long-term operation. The major disadvantage of the AF concept is the difficulty to maintain the required contact between sludge and wastewater, because clogging of the "bed" easily occurs. This is particularly the case for partly soluble wastewaters. These clogging problems - at least partly—can be overcome by applying a primary settler and/or a pre-acidification step (Seyfried 1988). However, this would require the construction and operation of additional units. Moreover, apart from the higher costs, it would not completely eliminate the problem of short-circuiting (clogging of the bed), leading to disappointing treatment efficiencies.

AF technology has been widely applied for treatment of wastewaters from the beverage, food-processing, pharmaceutical and chemical industries due to its high capability of biosolids retention (Ersahin et al. 2011). Since 1981, about 130-140 full-scale upflow AF installations have been put in operation for the treatment of various types of wastewater, which is about $6 \%$ of the total amount of installed high-rate reactors. The experiences with the system certainly are rather satisfactory; applying modest to relatively high loading rates up to $10 \mathrm{~kg} \mathrm{COD} \mathrm{m}^{-3}$ day $^{-1}$. The AF system will remain attractive for treatment of mainly soluble types of wastewaters, particularly when the sludge granulation process cannot occur satisfactory. On the other hand, long-term problems related to system clogging and the stability of filter material caused a decline in the number of installed full-scale AF systems.

\section{Sludge granulation}

The key for modern high-rate biotechnology, whatever system is considered, is immobilization of proper bacteria. In fact, the required high sludge retention in 
anaerobic sludge bed systems is based on immobilization, which generally leads to the formation of wellbalanced microbial consortia. The presence of these consortia is considered a prerequisite for proper anaerobic process operation, particularly considering the occurrence of various syntrophic conversion reactions in the anaerobic degradation of most organic compounds, the detrimental effect of higher concentrations of specific intermediates, and the strong effect of environmental factors like $\mathrm{pH}$ and redox potential. Significant progress in the knowledge of the fundamentals of the immobilization process has been made since the development and successful implementation of high-rate anaerobic treatment systems in the seventies (Hulshoff Pol et al. 2004). In the absence of fixed or free floating inert support material, a so-called "autoimmobilization" will occur, which is understood as the immobilization of bacteria on themselves or on very fine inert or organic particles present in the wastewater, forming dense bacterial conglomerates. The bacterial conglomerates will mature on due time and form round shaped granular sludge.

The phenomenon of sludge granulation has puzzled many researchers from very different disciplines. Granulation, in fact, is a completely natural process and proceeds in all systems where the basic conditions for its occurrence are met, i.e. on mainly soluble substrates applying HRTs lower than the bacterial doubling times. Owing to the very low growth rate of the crucial aceticlastic methanogenic bacteria, particularly under sub-optimal conditions, the latter conditions are easily met. Anaerobic granule formation is mostly observed in anaerobic bioreactors that are operated in upflow mode (Hulshoff Pol et al. 2004). However, successful granulation was also observed in anaerobic sequencing batch reactors (Sung and Dague 1995; Wirtz and Dague 1996). Maybe for the first time, sludge granulation was found to occur in the upflow Dorr Oliver Clarigesters applied in South Africa since the 1950s. However, this only became apparent by observation of sludge samples taken from such a digester in 1979 (Lettinga 2014). Surprisingly enough, no attention was given to the characteristics of the Clarigester sludge such as size, form and the mechanical strength, density and porosity of sludge flocs/ aggregates. Despite all the efforts made to develop systems with a high sludge retention, nobody apparently noticed that the major part of the sludge consisted of a granular type of sludge. While studying the start-up and feasibility of anaerobic upflow filters, Young and McCarty (1969) already recognized the ability of anaerobic sludge to form very well settleable aggregates. These granules were as large as $3.1 \mathrm{~mm}$ in diameter and settle readily. In AF experiments with potato starch wastewater and methanol solutions conducted in the Netherlands, similar observations were made (Lettinga et al. 1976, 1979). Whereas the interest in anaerobic wastewater treatment in the USA and South Africa diminished, large emphasis on developing industrial scale systems was put in the Netherlands, where instalment of new surface water protection acts coincided with the world energy crisis of the seventies as outline above. As a result, increasing emphasis could be afforded on applied and fundamental research in this field, particularly also on the phenomenon of sludge granulation (Lettinga et al. 1987). A worldwide growing interest occurred from both the engineering and the microbiological field. As a result, the insight in the mechanism of the sludge granulation process for anaerobic treatment has been elucidated sufficiently, at least for practical application (e.g. De Zeeuw 1982, 1987; Hulshoff Pol and Lettinga 1986; Wiegant and de Man 1986; Hulshoff Pol et al. 1987, 2004; Dolfing 1987; Wu et al. 1991; van Lier et al. 1994; Fang et al. 1994; Liu et al. 2003; Song et al. 2010; Habeeb et al. 2011; Abbasi and Abbasi 2012; Subramanyam 2013). Granulation can proceed under mesophilic, thermophilic and psychrophilic conditions. It is considered of big practical importance to further unravel the fundamentals concerning the growth of mixed balanced granular aggregates, not only from the microbial but also from the process engineering point of view.

A variety of process operational and external factors are effective on granule stability, e.g. HRT, VLR, temperature, $\mathrm{pH}$, upflow velocity, presence of divalent cations and heavy metals, salinity, and nutrient availability (Habeeb et al. 2011; Abbasi and Abbasi 2012; Calderon et al. 2013; Ismail et al. 2008). The seed sludge and the chemical composition of the industrial wastewater have significant impact on the chemical composition of the granular sludge (Batstone et al. 2004). In addition, Macro- and micronutrients, e.g. iron, copper, calcium, magnesium, cobalt and aluminum are vital for the aggregation of the cells (Subramanyam 2013).

The morphological and spatial structure of granules in a UASB reactor was examined by MacLeod et al. 
(1990). They found that the granular aggregates were three-layered structures. Whereas the exterior layer of the granule contained a heterogeneous microbial population, the middle layer consisted of more homogeneous biomass. Moreover, the internal core consisted of a "single species", like Methanothrix-like cells, later renamed to Methanosaeta spec. (Patel and Sprott 1990). Similar findings have been reported in the study of Baloch et al. (2008), in which anaerobic granules were found to possess a multi-layered structure with complex microbial ecology and dominating methanogenic subpopulations. Apparently, Methanosaeta plays an important role in sludge granulation (Fang et al. 1994). The structured characteristics and layered 'ecological zones' of the granules were defined as a stable metabolic arrangement that creates optimal nutritional and environmental conditions for all microorganisms included in it (Guiot et al. 1992). The carbon source or substrate was considered the most important factor affecting the microstructure of the UASB granules (Grotenhuis et al. 1991; Fang et al. 1994; Batstone et al. 2004). The extent of required acidification and the acidogenesis rate of the substrate affects the concentration profiles of the substrate, metabolites in the granule and its structure. For example, granules in a UASB reactor treating sucrose and brewery wastewaters had a three-layered structure; however, the ones in a UASB reactor treating glutamate exhibited a rather uniform structure. McHugh et al. (2003) reported that, in a granule, a central core of acetoclastic methanogens is surrounded by a layer of hydrogen and/or formate producing acetogens, and hydrogen and/or formate consuming methanogens. Outside layer of this granule structure consists of microorganisms that hydrolyze and acidify the complex organic matter (Liu et al. 2003). Methanosaeta spp. populations have been found abundant in stable granules in various studies. Apparently, these organisms are necessary for the successful operation of anaerobic sludge bed reactors. Methanogens related to Methanosaeta spp. have a filamentous morphology, are more or less hydrophobic, have an electrophoretic mobility of about 0 , and are considered the most important component of the granule structure, providing support for other microorganisms in the granule (Grotenhuis et al. 1992, Song et al. 2010; Calderon et al. 2013). It is hypothesized that after the formation of such methanogenic nucleus, acetogenic bacteria adhere, followed by the formation of biofilm layers consisting of hydrogenotrophic methanogens (Abbasi and Abbasi 2012). On the other hand, the bacteriophage in the granular sludge may cause the breakdown of the granules (Subramanyam 2013).

Molecular techniques are increasingly used to study the microbial community structure of environmental ecosystems like anaerobic granular sludge without cultivation (Batstone et al. 2004). By using molecular techniques, Sekiguchi et al. (1999) localized the methanogens in anaerobic granular sludge systems. They showed that a significant fraction of the granule is inactive and this probably consists of cellular fragments. The spatial information associated with a protein or pathway inside the cell can influence the end-behavior of a molecular network (Agapakis et al. 2012). Satoh et al. (2007) combined 16S rRNA genebased molecular techniques with microsensors to provide direct information about the phylogenetic diversities, spatial distributions, and activities of bacteria and archaea in anaerobic granules. They found that acid and $\mathrm{H}_{2}$ production occurred in the outer part of the granule, below which $\mathrm{H}_{2}$ consumption and $\mathrm{CH}_{4}$ production were found.

In essence, sludge granulation finds its ground in the fact that bacterial retention is imperative when dilution rates exceed the bacterial growth rates (van Loosdrecht et al. 2002). Immobilization further requires the presence of support material and/or specific growth nuclei (Hulshoff Pol et al. 1983), as well as the presence of exopolymeric substances (EPS) acting as a kind of glue creating a microbial matrix (Vanderhaegen et al. 1992). The occurrence of granulation can be explained as follows:

- Proper growth nuclei, i.e. inert organic and inorganic bacterial carrier materials as well as bacterial aggregates, are already present in the seed sludge.

- Finely dispersed matter, including viable bacterial matter, will become decreasingly retained, once the superficial liquid and gas velocities increase, applying dilution rates higher than the bacterial growth rates under the prevailing environmental conditions. As a result, film and/or aggregate formation automatically occurs.

- The size of the aggregates and/or biofilm thickness are limited, viz. it depends on the intrinsic strength (binding forces and the degree of bacterial intertwinement) and the external forces exerted on the particles/films (shear stress). Therefore, at due 
time, particles/films will fall apart, evolving a next generation. The first generation(s) of aggregates, indicated by Hulshoff Pol et al. (1983) as "filamentous" granules, are quite voluminous and in fact more a flock than a granule.

- Retained secondary growth nuclei will grow in size again, but also in bacterial density. Growth is not restricted to the outskirts, but also proceeds inside the aggregates. At due time, they will fall apart again, evolving a third generation, etc.

During the above described selection process, both organic and hydraulic loading rates gradually increase, increasing the shear stress inside the system. For mainly soluble wastewaters that are partly acidified, granular sludge will be easily cultivated. Table 2 lists some common characteristics of methanogenic granular sludge.

\section{Upflow anaerobic sludge blanket (UASB) reactors}

One of the most remarkable and significant developments in high-rate anaerobic treatment technology is the invention of UASB reactor by Lettinga et al. (1976, 1980) in Netherlands. The sludge retention in such a reactor is based on the formation of well settleable sludge aggregates (flocs or granules), and on the application of a reverse funnel-shaped internal gasliquid-solids separation (GLSS) device. Many successful performance results have been reported at laband pilot-scale applications using anaerobic granular sludge bed processes, which resulted in the establishment of thousands of full-scale reactors worldwide (Nnaji 2013; Lim and Kim 2014; van Lier 2008). Anaerobic sludge bed reactors, undoubtedly, are by far the most popular anaerobic wastewater treatment systems so far, having a wide application potential in industrial wastewater treatment. In view of its prospects, and the fact that almost $90 \%$ of the newly installed high-rate reactors are sludge bed systems (van Lier 2008), the UASB process will be elaborated in more detail than the other systems.

The first UASB reactors were installed for the treatment of food, beverage and agro-based wastewaters, rapidly followed by applications for paper and board mill effluents in 1983 (Habets and Knelissen 1985). Most of the full-scale reactors are used for treating agro-industrial wastewater, but the applications for the treatment of wastewaters from chemical industries are increasing, as discussed below (van Lier 2008; Rajagopal et al. 2013). Similar to the AF system, the wastewater moves in an upward flow through the UASB reactor. However, contrary to the AF system, no packing material is present in the UASB reactor. Good settle-ability, low HRTs, elimination of the packing material cost, high biomass concentrations

Table 2 Proposal for definition and characteristics of good quality granular sludge (photos: Paques BV)

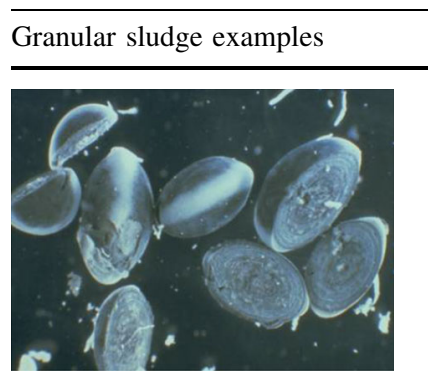

Potato wastewater grown granules

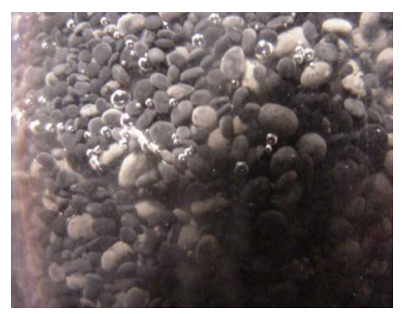

Settleability and other physical properties:

Settling velocities: $2-100 \mathrm{~m} \mathrm{~h}^{-1}$; typically: $30-75 \mathrm{~m} \mathrm{~h}^{-1}$

Density: $1.00-1.05 \mathrm{~g} \mathrm{~L}^{-1}$

Diameter: $0.1-8 \mathrm{~mm}$; typically: $0.15-4 \mathrm{~mm}$

Shape: spherical formed and well defined surface

Color: black/gray/white

Paper mill wastewater grown granules 
(up to $80 \mathrm{~g} \mathrm{~L}^{-1}$ ), effective solids/liquid separation, and operation at high VLRs can be achieved by UASB reactor systems (Speece 1996). The design VLR is typically in the range of $4-15 \mathrm{~kg} \mathrm{COD} \mathrm{m}^{-3}$ day (Rittmann and McCarty 2001). One of the major limitations of this process is related to wastewaters having a high SS content, which hampers the development of dense granular sludge (Alphenaar 1994). The sludge bed reactor concept is based on the following ideas:

- Anaerobic sludge has or acquires good sedimentation properties, provided the process is operated correctly. Small particles or slowly settleable sludge will be washed-out from the system.

- The required good contact between the sludge and wastewater in UASB reactors generally is accomplished by feeding the wastewater as uniformly as possible over the bottom of the reactor. Also the increased up-flow velocity results in a better contact between the sludge particles and the pollutants. At VLRs exceeding $5 \mathrm{~kg}$ COD m $\mathrm{m}^{-3}$ day $^{-1}$, mixing of sludge and wastewater is brought about by biogas turbulence. Mechanical mixing is not applied in UASB reactors.

- With wastewaters containing biodegradable inhibitory compounds, the hydrodynamic mixing is additionally achieved by applying a liquid recirculation flow. As a result, a more completely mixed flow pattern is acquired and stratification of the substrate and intermediate products over the height of the reactor is minimized, thereby minimizing potential inhibition.

- The wash-out of the active sludge aggregates is prevented by separating the produced biogas using a gas collection dome installed at the top of the reactor. In this way, a zone with relatively little turbulence is created in the uppermost part of the reactor, in fact functioning as an in-built secondary clarifier.

- The GLSS-device constitutes an essential part of a UASB reactor and serves the following functions:

1. To collect, separate and discharge the produced biogas. For a satisfactory performance the gas-liquid surface area within the device should be sufficiently large, so that gas can evade easily. This particularly is important in case scum layers would develop.
2. To reduce liquid turbulences in the settler compartment (resulting from bio-gas production), enhancing sludge settling.

3. To retain sludge particles by a mechanism of sedimentation, flocculation.

4. To limit the expansion of the sludge bed towards the settler compartment.

5. To reduce or prevent that buoying sludge particles underneath the gas dome wash out from the system.

Some researchers and practitioners suggest replacing the GLSS-device by a packed bed in the upper part of the reactor. This so-called up-flow hybrid reactor combines a UASB reactor in the lower part with an AF in the upper part and promotes the advantages of both reactor types. Anaerobic hybrid reactors have been applied for treatment of various kinds of industrial wastewaters and domestic wastewaters (e.g. Monroy et al. 2000; Banu et al. 2007). The first study on the performance of a hybrid reactor was reported by Guiot and van den Berg (1984) who obtained a high efficiency in retaining biomass by using packing material in a hybrid reactor (UASB $+\mathrm{AF}$ ). It is reported that performance of high rate anaerobic sludge bed reactors has significantly increased by locating the packing material to the top 25-30\% of the reactor (Guiot and van den Berg 1985). Kennedy and Guiot (1986) reported that hybrid reactor systems were able to withstand severe organic shock loads and recover within a reasonable period of time. They achieved a COD removal rate of $95 \%$ at an OLR of $33 \mathrm{~kg} \mathrm{COD} \mathrm{m}^{-3}$ day in an anaerobic hybrid system treating municipal landfill leachate. Similarly, an anaerobic hybrid reactor was successfully used with a COD removal efficiency of $97 \%$ for the treatment of dairy effluents (Strydom et al. 1997). The performance of hybrid up-flow AF depends on the contact of the wastewater with both the attached biofilm in the media and suspended growth in the sludge bed part (Buyukkamaci and Filibeli 2002). In some designs, the packing material is mounted only in the settling compartment leaving the GLSS at its original position. About $2-3 \%$ of all anaerobic reactors installed are hybrid reactors. In most applications, the majority of organic matter conversion is located in the sludge bed section whereas the removal of a specific fraction of pollutants is located in the filter area at the top. 
Specific chemical wastewaters show better treatment efficiencies for all compounds using hybrid systems compared to UASB reactor. Ramakrishnan and Gupta (2008) investigated the biodegradation of complex phenolic mixture in an anaerobic hybrid reactor that was a combination of UASB reactor and AF. They found that the optimum $\mathrm{COD} / \mathrm{NO}_{3}-\mathrm{N}$ ratio for maximum COD and phenolics removal was about 6.4. At this ratio, the removal of COD and phenolics were 96 and $99 \%$, respectively. Kleerebezem et al. (1999a, b) performed lab research on the treatment of purified therephthalic acid (PTA) wastewater. Their results showed that the conversion of therephthalic acid to benzoate is only possible at low concentrations of acetate and benzoate. By applying a hybrid system, the latter two are converted in the sludge bed area, whereas therephthalic acid and other refractory compounds are then converted in the hybrid section, where specific flora is retained. Despite of these laboratory findings, full scale anaerobic plants treating PTA wastewater merely consist of a single stage sludge bed system. Since these reactors are generally followed by an activated sludge post-treatment system, any nondegraded aromatic is subsequently aerobically converted. Full scale anaerobic reactors treating PTA wastewaters are generally characterized by good treatment efficiencies. In addition to PTA, several other chemical wastewaters are typically treated by anaerobic reactor systems as reviewed by Macarie (1999) and Kleerebezem and Macarie (2003). Although some full scale reactors consist of hybrid systems, single sludge bed systems seems to be preferred; after prolonged periods of operation the filter sections at the top part of the reactor often deteriorate.

\section{Fluidized and expanded bed systems (FB, EGSB, IC reactors)}

Fluidized bed and expanded bed systems are regarded as the second generation of anaerobic sludge bed reactors achieving extreme VLRs (at labscale: 30-60 kg COD m ${ }^{-3} \mathrm{day}^{-1}$, at full scale: $20-40 \mathrm{~kg}$ $\mathrm{COD} \mathrm{m}^{-3} \mathrm{day}^{-1}$ ). The $\mathrm{FB}$ process is based on the occurrence of bacterial attachment to non-fixed or mobile carrier particles, which consist, of e.g. fine sand $(0.1-0.3 \mathrm{~mm})$, basalt, pumice, or plastic. The FB system can be regarded as an advanced anaerobic technology (Heijnen et al. 1990; Li and Sutton 1981), which may reach loading rates exceeding $40 \mathrm{~kg}$

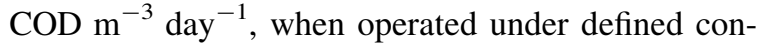
ditions (Moletta et al. 1994). Good mass transfer resulting from (1) liquid turbulence and high flow rate around the particles, (2) less clogging and less shortcircuiting due to the occurrence of large pores through bed expansion, and (3) high specific surface area of the carriers due to their small size, make FB reactors highly efficient. However, long-term stable operation appears to be problematic. The system relies on the formation of a more or less uniform (in thickness, density, strength) attached biofilm and/or particles. In order to maintain a stable situation with respect to the biofilm development, a high degree of pre-acidification is considered necessary and dispersed matter should be absent in the feed (Ehlinger 1994). Despite that, an even film thickness is very difficult to control and in many situations a segregation of different types of biofilms over the height of the reactor occurs. In full-scale reactors, bare carrier particles may segregate from the biofilms leading to operational problems. In order to keep the biofilm particles in the reactor, flow adjustments are necessary, after which the support material will start to accumulate in the lower part of the reactor as a kind of stationary bed, whereas light fluffy aggregates (detached biofilms) will be present in the upper part. Retention of these fluffy aggregates can only be accomplished when the superficial velocity remains relatively low, which in fact is not the objective of an FB system.

Modern FB reactors like the Anaflux system (Holst et al. 1997) rely on bed expansion rather than bed fluidization. As bed expansion allows a much wider distribution of prevailing biofilms, the system is much easier to operate. Like in the conventional AF systems an inert porous carrier material (particles $<0.5 \mathrm{~mm}$, density about 2) is used for bacterial attachment in the Anaflux system. The Anaflux reactor uses a triple phase separator at top of the reactor, more or less similar to the GLSS device in UASB reactors. When the biofilm layer attached to the media becomes excessively over-developed and the concerning (lighter) aggregates subsequently accumulate in the separator device, the material is periodically extracted from the reactor by an external pump, in which it is subjected to sufficient shear to remove part of the biofilm. Then, both the media and detached biomass are returned to the reactor, and the free biomass is then 
allowed to be washed out from the system. In this way the density of the media is controlled and a more homogeneous reactor bed is created. Up to $30-90 \mathrm{~kg}$ volatile suspended solids (VSS) $\mathrm{m}^{-3}$, reactor can be retained in this way and because of the applied high liquid upflow velocities, i.e. up to $10 \mathrm{~m} \mathrm{~h}^{-1}$, an excellent liquid-biomass contact is accomplished. The system is applicable to wastewaters with a SS concentration $<500 \mathrm{mg} \mathrm{L}^{-1}$. Most of the full-scale anaerobic FB reactors are installed as Anaflux processes. Nonetheless, at present, the EGSB reactors are much more of commercial interest for full scale applications than the more expensive FB systems.

The EGSB reactor can be considered an upgrade of the conventional UASB reactor. The EGSB system employs granular sludge, which is characterized by good settling characteristics and a high methanogenic activity. As a consequence, the applied VLR and upward flow velocities are distinctly higher in EGSB reactors compared to UASBs. Sludge bed expansion is achieved by prevailing process conditions. When applying extreme sludge loading rates, the settleability will reduce owing to the biogas hold-up in the granules. Nonetheless, because of the high sludge settle-ability also high superficial liquid velocities, i.e. exceeding $6 \mathrm{~m} \mathrm{~h}^{-1}$, can be applied. These high liquid velocities, together with the lifting action of gas evolved in the bed, leads to a (modest) expansion of the sludge bed. And as a result of that, an excellent contact between sludge and wastewater prevails in the system, leading to significantly higher loading potentials compared to conventional UASB installations. In some expanded bed systems, e.g. the Biopaq ${ }^{\circledR} \mathrm{IC}$ reactor, the superficial flow velocities, resulting from both hydraulic and gas flows, may range to 25-30 $\mathrm{m} \mathrm{h}^{-1}$, causing an almost complete mixing of the reactor medium with the available biomass.

Excellent results have been obtained with modern full-scale EGSB installations, such as the Biobed EGSB and Biopaq ${ }^{\circledR} \mathrm{IC}$ reactors, using various kinds of wastewaters and applying VLRs of $25-35 \mathrm{~kg}$ COD $\mathrm{m}^{-3}$ day $^{-1}$. The extreme COD loading rates of EGSB type systems result in extreme biogas loading rates following:

$$
\begin{aligned}
V_{\text {biogas }}= & \text { CODconc. } \frac{E_{f f-\text { meth }}}{100} \cdot \frac{0.35}{F_{\text {meth-biogas }}} \cdot \frac{(T+273)}{273} \\
& \cdot V_{\text {upw }, \text { liquid }}
\end{aligned}
$$

In which, $\mathrm{E}_{\mathrm{ff}-\mathrm{meth}}=$ amount of $\mathrm{COD}$ converted to $\mathrm{CH}_{4}$ or $\mathrm{COD}$ efficiency based on $\mathrm{CH}_{4}$ production, $\mathrm{F}_{\text {meth- }}$ biogas $=$ fraction of methane in biogas (e.g. 0.6 for $\left.60 \% \mathrm{CH}_{4}\right), \mathrm{T}=$ operational temperature of UASB reactor in ${ }^{\circ} \mathrm{C}, \mathrm{V}_{\text {upw, liquid }}=$ upward liquid velocity in UASB reactor. Generally, a biogas loading rate of no more than 2-3 $\mathrm{m}^{3} \mathrm{~m}^{-2} \mathrm{~h}^{-1}$ are applied for conventionally designed GLSS devices in UASB reactors. For biogas loading rates exceeding these values, more advanced gas separators are required. EGSB reactors have a high height-diameter ratio, with reactors heights reaching up to $25 \mathrm{~m}$. Consequently, biogas turbulence accumulates from bottom to top. Since the EGSB systems rely on a complete retention of the granular sludge, efficient sludge separation at the top part of the system is of utmost importance. The various contractors supplying EGSB reactors, have their own typical features for separating actively the sludge from the liquid and gas flow, applying specifically designed GLSS units. It may be clear that under EGSB conditions, conventionally designed GLSS devices are of no use. Interestingly, by applying an EGSB reactor system, several other types of wastewaters can be treated that cannot be treated using conventional UASB systems. Examples are:

- Wastewaters containing highly toxic but anaerobically degradable components. Treatment of these wastewaters requires that external or internal dilution keeps the toxicant concentration to which the biomass is exposed sufficiently low. For example, full-scale reactors have shown stable performance over many years treating wastewaters with high formaldehyde concentrations, reaching values to about $10 \mathrm{~g} \mathrm{~L}^{-1}$ (Zoutberg and Frankin 1996; Zoutberg and De Been 1997).

- Wastewater containing dyes and other toxic textile auxiliary compounds can be successfully converted into biogas without inhibitory effects on the biomass (Frijters et al. 2006)

- Cold $\left(<10^{\circ} \mathrm{C}\right)$ and dilute $\left(\mathrm{COD}<1 \mathrm{~g} \mathrm{~L}^{-1}\right)$ wastewaters, i.e. when specific gas production is very low and biogas mixing is absent (Rebac et al. 1998). EGSB reactors are characterized by an improved hydraulic mixing, independent from the biogas production. As a consequence and in contrast to UASB systems, all retained sludge is optimally mixed with the incoming wastewater, 
while small inactive particles are washed-out from the system.

A special version of the EGSB concept is the so-called Internal Circulation (Biopaq ${ }^{\circledR} \mathrm{IC}$ ) reactor (Vellinga et al. 1986). In this type of reactor, the produced biogas is separated from the liquid halfway the reactor by means of an in-built GLSS device and conveyed upwards through a pipe to a degasifier unit or expansion device. Here, the separated biogas is removed from the system, whereas the sludge-water mixture drops back to the bottom of the reactor via another pipe. In fact, the lifting forces of the collected biogas are used to bring about a recirculation of liquid (and granular sludge) over the lower part of the reactor, which results in an improved contact between sludge and wastewater. The extent of liquid/sludge recirculation depends on the gas production (Vellinga et al. 1986; Pereboom and Vereijken 1994; Habets et al. 1997).

\section{Anaerobic baffled (staged) reactors (ABR)}

Where ACP, UASB and EGSB reactors are based on a mixed to completely mixed reactor content, various designs have been tested that employ staging of the various phases of anaerobic treatment, creating a plugflow in the waterline (van Lier et al. 2001). An extreme example is the two stage process where the acidification step is completely separated from the methanogenic step. Although a complete separation of these steps initially showed good results at laboratory scale research, in practice, pre-acidification is generally combined with influent buffering (Lettinga and Hulshoff Pol 1991; van Lier et al. 2001). In fact, a too high degree of pre-acidification negatively impacts stable granule formation. One hand, the SS which are formed during acidification and which are subsequently carried over to the methanogenic reactor, deteriorate the granular sludge bed stability (Alphenaar 1994). On the other hand, the occurrence or presence of fermentative substrate conversion by acidifying organisms is indispensable for the production of sufficient EPS which are required for the formation of a stable granular structure with a high granule strength (Vanderhaegen et al. 1992). Various authors suggested that the EPS are particularly produced by acidifying organisms, creating the matrix in which all bacteria and archaea are embedded (Batstone and Keller 2001; Fukuzaki et al. 1995; Puñal et al. 2003). At present, in most full scale applications, a pre-acidification of maximally $40 \%$ is pursued.

Horizontal staging is obtained in ABRs, which is best characterized as a series of serially operated upflow units without GLSS devices (Bachmann et al. 1985; Barber and Stuckey 1999). Although some larger scale applications were made on domestic sewage, the reactor has not been developed further than the pilot scale (Zhu et al. 2015). A problem of concern is the hydrodynamic limitation giving constraints to the achievable SRT in the system, since the superficial liquid velocity in a baffled system is substantially higher than in a single step sludge bed reactor. As a result, the sludge mass may slowly move with the liquid flow through the various compartments. Vertically staged reactors like the upflow staged sludge bed system (Van Lier et al. 1994, 2001; Guiot et al. 1995; Tagawa et al. 2002) overcome this problem and were specifically developed for high temperature treatment. Although the staged reactor concept showed very promising results on pilot-scale, also for this type of high-rate reactor, full-scale reactors are very scarce.

\section{High-rate reactors with advanced sludge-liquid separation}

\subsection{Reactors with advanced settling or flotation for sludge retention}

Most, if not all, researches on anaerobic sludge granulation, and factors impacting the granule growth, has been conducted under lab-scale conditions (Hulshoff Pol et al. 2004, Subramanyam 2013). However, the predictive value of the many lab-scale researches might be questioned, realizing the complete different hydrodynamic conditions prevailing in the full scale high rate reactors. In fact, the prevailing shear forces are from another order, meaning that full scale experiences on a similar wastewater can be very different from the carefully conducted lab tests. Disappointing granule formation restricts contractors in offering proper anaerobic high-rate reactors to industries for treating their wastewater. In those situations, conventional sludge bed reactors might then be offered, such as the UASB, of which the 
treatment efficiency is not dependent on the presence of granular sludge. Also for the more complex types of wastewaters, such as those characterized by a high SS content, expanded bed reactors are not very appropriate. Under the prevailing flow conditions the SS will be washed-out from the system, and/or the more heavier SS may negatively impact granule formation and granule growth (Alphenaar 1994). Also during the treatment of wastewaters that are characterized by COD concentrations exceeding $50 \mathrm{~g} \mathrm{~L}^{-1}$, e.g. distillery slops or vinasse, the cultivation of granular sludge is extremely difficult, if possible at all. Owing to the high influent COD concentrations, resulting HRTs are very long, drastically diminishing the hydraulic selective pressure inside the reactor, which is regarded crucial for sludge granulation (Hulshoff Pol et al. 2004). In the increasingly competitive market, however, contractors are forced to developed anaerobic high rate systems that are as robust as UASB reactors, whereas the COD loading potentials should reach the levels of EGSB systems, although the presence of granular sludge cannot be guaranteed. This calls for more enhanced sludge-solids separation devices that can operate under high hydraulic flow conditions, but which are not dependent on discrete particle settling as is more or less the case with granular sludge. Enhanced flocculent sludge-liquid separation can be established by (1) physically enhanced settling, (2) flotation, or (3) filtration. The novel reactor systems making use of this principle are explained below.

Physically enhanced settling can be achieved by mounting a tilted plate settling device for sludge liquid separation into the bioreactor. In fact, Biothane Systems International already incorporating a tilted plate settler into the GLSS device in their BioBed ${ }^{\circledR-}$ EGSB system (Zoutberg and Frankin 1996; Zoutberg and De Been 1997). In the past years, the Dutch contractor Paques applied this idea to an upflow sludge bed reactor with a high height-diameter ratio, in a system denominated as the Biopaq ${ }^{\circledR}$ UASBplus (Fig. 2). Although the UASBplus sludge separator device also can be employed for the retention of anaerobic granules, it is very well suitable for anaerobic flocculent sludge, which is prevalent in case of more concentrated wastewater, like bioethanol waste(water), e.g. vinasse. At present 25 full scale UASBplus systems are operational of which approximately $1 / 3$ of the reactors contain flocs or small aggregates; most UASBplus reactors are installed in China.

Sludge separation by flotation is a well-known preand post-treatment technique to separate small particles, low-density floating mass, and/or hydrophobic compounds such as fats, oil, and grease (FOG) from the liquid. Particularly the presence of FOG in wastewaters may cause problems with sludge flotation and sludge wash-out in both UASB and EGSB reactors (Hwu et al. 1997a, b). However, the buoyant force of entrapping biogas in FOG-loaded anaerobic sludge can also be used to separate the reactor sludge from the discharging effluent by mounting the flotation device inside the anaerobic reactor. In this way, the effluent is clarified, meanwhile the active methanogenic sludge is retained in the bioreactor. The Dutch contractor Paques developed this so-called anaerobic flotation reactor, denominated as the Biopaq ${ }^{\circledR}$ AFR, to convert high concentrations of fats and oils into methane (Fig. 2). The AFR system is successfully applied in 3 full scale projects, two at dairy/food industries in the Netherlands treating each $4000 \mathrm{~kg} \mathrm{COD} \mathrm{day}{ }^{-1}$ (Frijters et al. 2014) and one treating $163,000 \mathrm{~kg}$ $\mathrm{COD} \mathrm{day}^{-1}$ wastewater from a bio-ethanol industry in China.

The separation of active methanogenic sludge from the bulk liquid by filtration is applied in anaerobic MBR systems. In AnMBR systems (see next section) the biomass is present in very small flocks, or even in single cells (Jeison and van Lier 2007).

\subsection{Membrane coupled anaerobic reactors}

In recent years, with growing application experiences from aerobic MBRs, AnMBRs have received much attention, particularly for those applications where the commonly applied sludge bed systems are less successful. AnMBRs combine the advantages of both MBR and anaerobic technology (Dereli et al. 2012; Ersahin et al. 2014). Operational costs related to energy requirements for gas/liquid recirculation for membrane fouling control and chemical costs required for membrane cleaning are still heavy burdens on the economic feasibility of AnMBRs. However, membrane acquisition and/or replacement costs have decreased significantly due to a decline in membrane module costs (Ozgun et al. 2013). Despite those constraints, AnMBRs offer high quality effluents free of solids and complete retention of biomass, regardless 


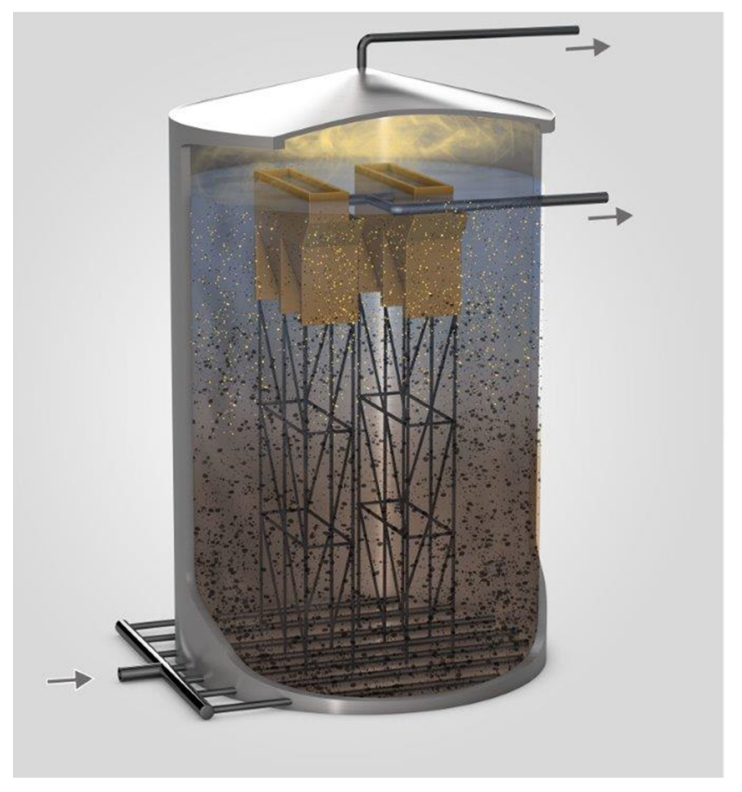

Fig. 2 Schematic representation of (left) the Biopaq ${ }^{\circledR U A S B}-$ plus reactor for the treatment of concentrated wastewaters and (right) the Biopaq ${ }^{\circledR}$ AFR reactor for the treatment of FOG-rich

their settling and/or granulation properties. Furthermore, AnMBRs can be used to retain special microbial communities that can degrade specific pollutants in the wastewater. Therefore, AnMBR technology may present an attractive option for treating industrial wastewaters at extreme conditions, such as high salinity (Yang et al. 2013), high temperature (Jeison et al. 2009), high SS concentrations (Jeison et al. 2008) and presence of toxicity (Muñoz Sierra et al. 2014), that hamper granulation and biomass retention or reduce the biological activity (Dereli et al. 2012). Industrial wastewaters with extreme physicochemical characteristics will likely occur more often in the future as cleaner industrial production processes require reduction of water consumption, water reuse and resource recovery (van Lier 2008; Dereli et al. 2012). Futselaar et al. (2013) claim that it is possible to obtain higher COD to methane conversion efficiencies in AnMBRs in comparison to conventional UASB reactors for the treatment of industrial wastewaters.

Combinations of membranes with different types of high-rate anaerobic reactor configurations such as CSTR, ACP, UASB, EGSB, FB, and hybrid reactors seem possible alternatives for treatment of industrial wastewaters (Ozgun et al. 2013). However, membrane integration eliminates the hydraulic selection pressure

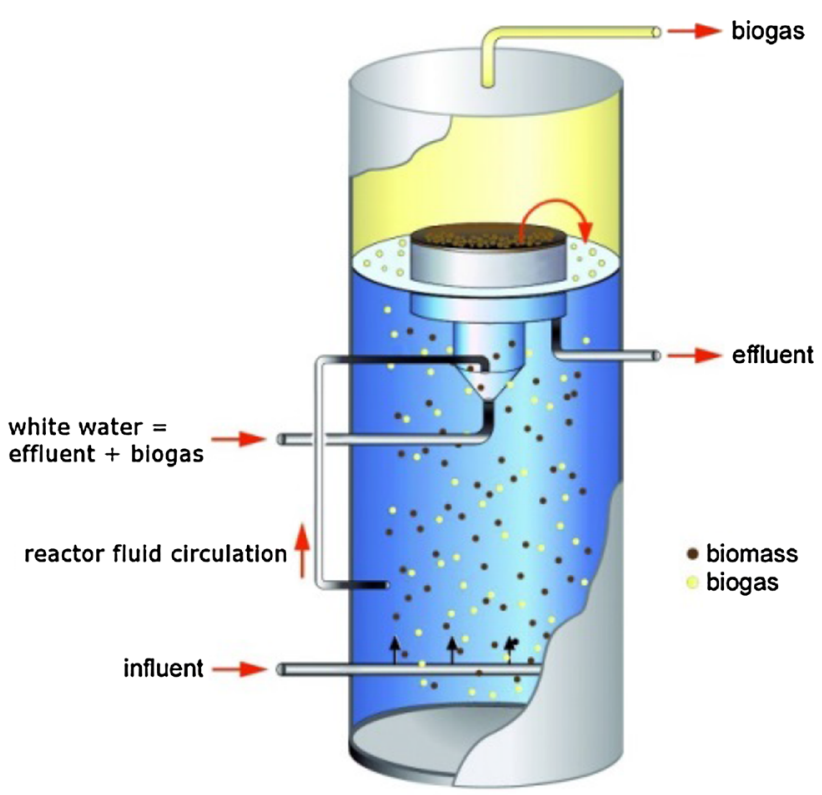

wastewater, in which sludge separation is based on sludge flotation. Reactors operate with either granular or flocculent sludge

required for granulation whereas flocculent biomass with poor immobilization characteristics is retained instead of washed-out. Moreover, by applying cross flow filtration, the prevailing shear forces will minimize the particle's diameter. Therefore, no granulation is expected in sludge bed reactors coupled to membrane filtration, which would decrease the settleability of the biomass on the long-term operation. Nonetheless, a sequenced approach of a UASB reactor followed by separate membrane modules offers interesting perspectives for full treatment. The preceding UASB provides a pre-elimination of SS by entrapment and biodegradation in the sludge bed, which reduces the SS load to the membrane and thus minimizes membrane fouling related to cake layer formation (Ozgun et al. 2013). Most researched AnMBR systems consist of a CSTR bioreactor coupled to cross-flow membrane skids or a CSTR bioreactor equipped with submerged membrane modules.

Successful commercial implementation of AnMBR technology started in the early 2000s. In Japan, Kubota realized 13 rather small-scale plants with flow rates up to $2.5 \mathrm{~m}^{3} \mathrm{~h}^{-1}$ using flat-sheet submerged membranes. The same configuration was picked up at larger scale in the USA by ADI, where three full-scale systems have so far been realized from 2008 onward (Christian 
et al. 2011; Allison et al. 2013). The year 2008 also saw the construction of the first multi-tube demonstration scale AnMBR treating whey from a cottage cheese producer in the USA. This system utilized Pentair's (formerly Norit) ultrafiltration membranes. Based on this success, Biothane Systems International and Pentair co-developed a low-energy AnMBR system called Memthane. There are now 7 full-scale Memthane plants (see Table 3).

\section{Types of anaerobic high-rate reactors currently installed}

Although various high-rate reactors are available in the market, sludge bed systems are by far mostly applied. Van Lier (2008) presented a survey taken from various international contractors regarding their sales and concluded that of all installed reactors between 1981 and 2007, about $77 \%$ consisted of sludge bed systems, mainly UASB and EGSB/IC reactors. However, focusing on the period 2002-2007, the contribution of sludge bed reactors to the total sales was almost $90 \%$. These numbers illustrate the popularity of anaerobic sludge bed systems for wastewater treatment. In that survey (van Lier 2008) it was also recognized that the sales of conventional UASB reactors were declining, whereas the EGSB type of reactors were becoming more popular. This trend has continued and currently the sales of conventional UASB reactors dropped to low levels for both Dutch contractors Paques BV and BiothaneVeolia as depicted in Figs. 3 and 4, respectively.

In addition to the conventional UASB and EGSB reactor sales, it is of interest to see that also the new technologies are getting accepted by the market. For Paques this concerns the Biopaq ${ }^{\circledR}$ UASBplus and
Biopaq ${ }^{\circledR}$ AFR reactor (depicted in Fig. 2) as well as the Biopaq ${ }^{\circledR}$ UBOX reactor, which is a sequential anaerobic/aerobic single-reactor system for the treatment of municipal wastewater. In this system, the activated sludge compartment is vertically mounted on top of the UASB compartment (van Lier et al. 2010). For Biothane-Veolia the new technologies particularly concern the BioBulk CSTR and the Memthane AnMBR.

At present, owing to the concerns related to depleting fossil fuels and thus increasing energy prices, as well as to the ongoing concerns related to greenhouse gas emissions that are linked to fossil fuel consumption, anaerobic high-rate treatment receives renewed interest worldwide. Depending on the loading potentials of the various high-rate reactors and the anaerobic treatability of the wastewater, the energy potential of anaerobic reactor can be easily estimated. Table 4 lists the expected energy output and $\mathrm{CO}_{2}$ emission reduction when anaerobic high-rate treatment is applied, meanwhile the generated $\mathrm{CH}_{4}$ is used inside the industry instead of fossil fuel derived electricity. Any intermediate value can be derived by linear interpolation.

\section{Non-traditional applications of anaerobic high- rate reactors}

High-rate anaerobic biotechnology has a significant potential for the recovery of bio-energy by the treatment of medium and/or high strength wastewaters, particularly from those produced in agro-industries. High COD removal efficiencies with a biomethane production of about $250-350 \mathrm{~m}^{3}$ per ton removed COD can be recovered depending on the inert COD content of the substrate. At present, most

Table 3 Memthane AnMBR references as of February 2015

\begin{tabular}{llllccc}
\hline Year & Region & Industry & Membrane configuration & Reactor volume $\left(\mathrm{m}^{3}\right)$ & Load $\left(\mathrm{kg} \mathrm{COD} \mathrm{day}^{-1}\right)$ & Flow $\left(\mathrm{m}^{3} \mathrm{~h}^{-1}\right)$ \\
\hline 2015 & Africa & Dairy & Parallel & 2900 & 16,500 & 83 \\
2013 & Europe & Food + pet food & Parallel & 2400 & 20,000 & 39 \\
2013 & Europe & Food & Parallel & 1200 & 7500 & 15 \\
2012 & Europe & Dairy & Serial & 675 & 5500 & 23 \\
2012 & Americas & Bioethanol & Serial & 20,000 & 63,800 & 174 \\
2012 & Americas & Food & Serial & 1250 & 7500 & 18 \\
2012 & Americas & Food & Serial & 1700 & 10,200 & 21 \\
\hline
\end{tabular}


Fig. 3 Sales of anaerobic high rate reactors by Paques BV since the company's start-up (1981)

Fig. 4 Sales of anaerobic high rate reactors by Biothane-Veolia since the company's start-up (1976)
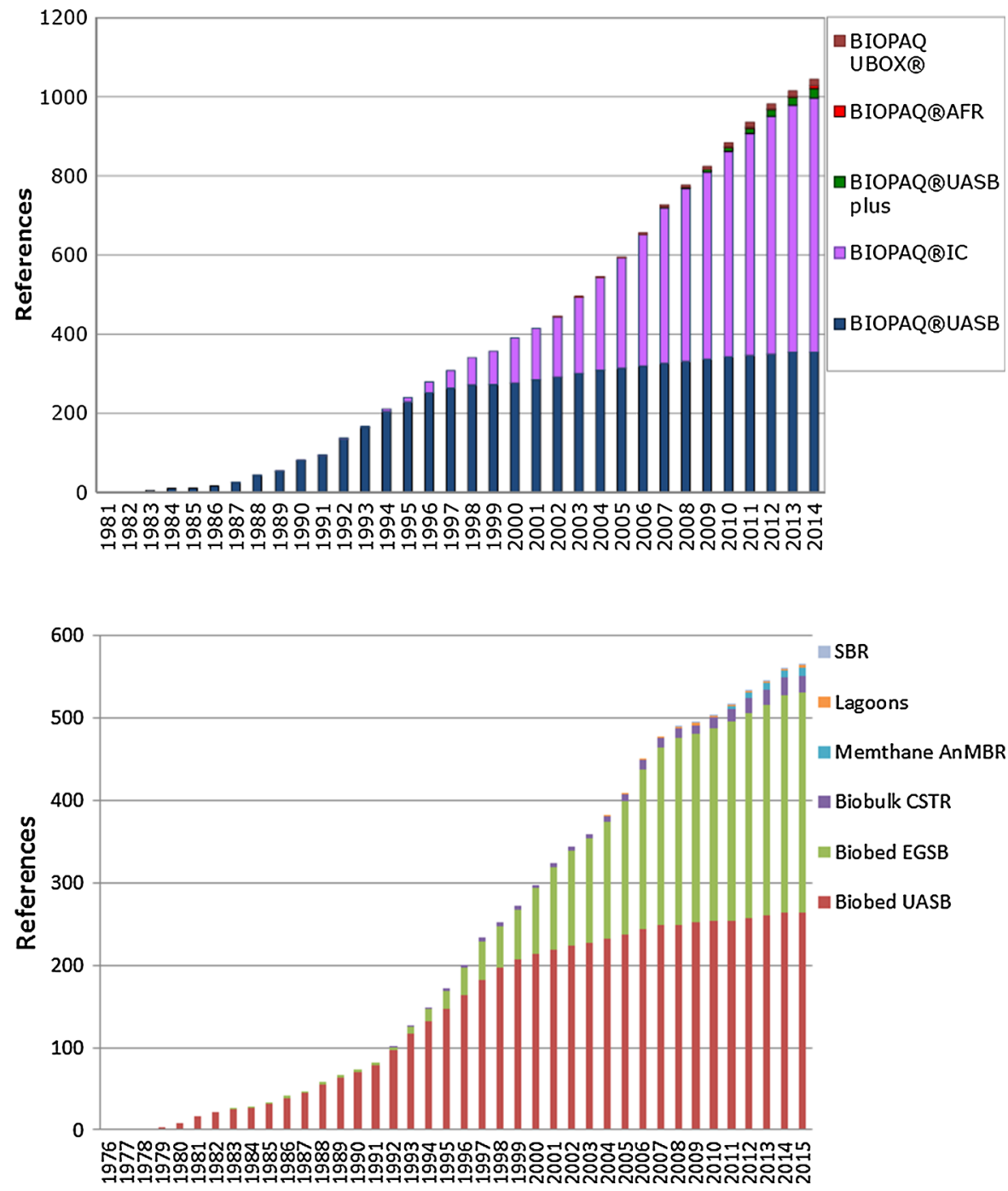

Table 4 Energy output and $\mathrm{CO}_{2}$ emission reduction applying anaerobic high-rate wastewater treatment systems (van Lier et al. 2008)

Parameter Values*

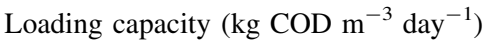

Energy output $\left(\mathrm{MJ} \mathrm{m}^{-3}\right.$ reactor installed day $\left.{ }^{-1}\right)$

Electric power output $\left(\mathrm{kW}-\mathrm{e} \mathrm{m}^{-3}\right.$ reactor installed)

$\mathrm{CO}_{2}$ emission reduction (ton $\mathrm{CO}_{2} \mathrm{~m}^{-3}$ year ${ }^{-1}$, based on coal-driven power plant)

* Assumptions: $80 \% \mathrm{CH}_{4}$ recovery relative to influent COD load and $40 \%$ electric conversion efficiency using a modern combined heat power generator. Intermediate values are obtained by linear interpolation

applications of anaerobic wastewater treatment can be found as end-of-the-pipe treatment technology for food processing wastewaters and agro-industrial wastewaters. In some recycle paper based paper mills, those which are producing corrugated or massive cardboard, inline treatment is applied consisting of 
sequenced anaerobic-aerobic treatment. These paper mills have no effluent and evaporated water in the paper drying section is replenished by fresh water (Habets and Knelissen 1997; van Lier and Boncz 2002).

The number of anaerobic applications in the nonfood sector is rapidly growing. Common examples are the paper mills and the chemical wastewaters, such as those containing formaldehyde, benzaldehydes, terephthalates, etc. (Razo-Flores et al. 2006). The latter is surprising, as the chemical industry usually has prejudices against biological treatment and anaerobic treatment in particular. Although various industrial wastewaters can be treated by anaerobic technology, various organic and inorganic materials in industrial wastewaters may be toxic to the anaerobic biomass. For example, some of the main problems encountered in the UASB reactors treating wastewaters from baker's yeast industries are the accumulation of the inorganic matter, i.e. struvite $\left(\mathrm{MgNH}_{4} \mathrm{PO}_{4}\right)$, but also ammonia toxicity due to high $\mathrm{pH}$ values, and high hydrogen sulphur content in the biogas. Another example is the biodegradable cyanide, which is present in some food processing wastewaters, and which is known to be inhibitory to acetoclastic methanogens (Zaher et al. 2006). Alkaloid wastewaters can be given as another example of refractory and inhibitory wastewaters, which contains some toxic organic chemicals such as N,N-dimethylaniline and toluene that are inhibitory for anaerobic biomass (Aydin et al. 2010). However, many organic toxicants can be anaerobically biodegraded if precautions are provided, e.g. gradual increase in toxicant concentration during start-up period and prevention of biomass wash-out until acclimation is completed. With regard to the chemical compounds, it is of interest to mention that certain compounds, such as poly chloro-aromatics and poly nitro-aromatics as well as the azo-dye linkages can only be degraded when a reducing (anaerobic) step is introduced in the treatment line (van Lier et al. 2001; Dos Santos et al. 2007). Anaerobics are then complementary to aerobics for achieving full treatment. For textile wastewater this is shown at full scale: the wastewater can be decolorized and detoxified in a serial full scale anaerobic-aerobic treatment system (Frijters et al. 2006). At full scale, the application of a sequenced anaerobic-aerobic wastewater treatment system is commonly applied for the treatment of industrial wastewaters. In such system, which may consist of an anaerobic high-rate process followed by an activated sludge process, the energy required for aeration and the amount of excess sludge in the aerobic second stage is significantly reduced when using an anaerobic first stage. In addition, with a net energy production in the first anaerobic stage, the total energy efficiency of the treatment plant can be increased, even becoming a net energy producer. Moreover, when industries are hampered by a limited aerobic wastewater treatment capacity, the implementation of an anaerobic first stage will significantly relieve this pressure, even giving potentials to increase the industrial production capacity without having the need for enlarging the aerobic treatment step.

The treatment of cold and very low-strength wastewaters can be achieved by applying optimised hydraulic mixing conditions in sludge bed reactors (Rebac et al. 1999, 1998). In addition to municipal sewage, many industrial wastewaters are discharged at low temperatures, e.g. beer and maltery wastewaters. A more recent example shows the successful longterm treatment of medium strength cereal-processing wastewaters under low temperature $\left(17^{\circ} \mathrm{C}\right)$ conditions at an HRT of $5.2 \mathrm{~h}$ using a pilot-scale UASB reactor (Esparza Soto et al. 2011). Full-scale results so far show that all of the cited wastewaters are anaerobically treated using common seed materials, illustrating the robustness and flexibility of the anaerobic process.

The application of high-rate anaerobic treatment to novel type of industrial wastewaters is generally preceded by pilot plant testing and extensive lab-scale research. However, in the past 15 years considerable progress is achieved in developing mathematical models and simulation programs, which can partly overcome the extensive lab tests, provided all wastewater characteristics are known. Mathematical modelling also can be used as a valuable tool to determine the effects of different operation alternatives or to assess the optimum conditions for the maximization of the biogas production capacity in anaerobic systems. By using mathematical modelling, it is possible to obtain insights in dynamic responses to changes in influent flow characteristics (Ersahin et al. 2007). Although various kinetic models were developed in the past 50 years, the Anaerobic Digestion Model No. 1 (ADM1), developed by the IWA Task Group for Mathematical Modelling on Anaerobic Digestion, is 
one of the most popular models used for simulation of sludge bed reactors in the past 15 years. In fact, ADM1 aggregates various existing models, whereas the structure of ADM1 is similar to that of the IWA activated sludge models, using similar notations for parameters, state variables and constants (Batstone et al. 2002). Although ADM1 was initially used to describe the anaerobic digestion of excess waste activated sludge, its generic structure also allows modelling of high-rate anaerobic processes for industrial wastewater treatment (Batstone et al. 2002; Dereli et al. 2010). The effect of different process alternatives and shock loadings on the system can be investigated by using a verified model. At present, ADM1 has been successfully applied to modelling of full-scale anaerobic sludge bed reactors treating different kinds of industrial wastewaters (Batstone and Keller 2003; Batstone et al. 2004; Ersahin et al. 2007; Chen et al. 2009; Dereli et al. 2010; Hinken et al. 2014; Barrera et al. 2015).

\section{Final remarks}

Sludge bed systems played a key role in the acceptance of high-rate anaerobic reactor systems for the treatment of industrial wastewater. UASB reactors and expanded bed related systems are applied at a large variety of industrial sites, offering cost-effective solutions to comply with legislative constraints in combination with a complementary technology. Reduced costs for treatment and bio-energy recovery lowers the threshold to indeed implement industrial wastewater treatment on the industrial premises. Onsite treatment of these wastewaters opens perspectives for resource recovery (bio-energy, process water) and reuse in the industrial process. Such development is regarded important for developing the so-called 'green industrial approach'. Decades of development of highrate anaerobic reactor systems expanded the application potential enormously, currently also including the more extreme type of wastewaters. For conditions where sludge immobilization or granulation cannot be guaranteed, novel high-rate reactors equipped with advanced sludge retentions systems may offer the appropriate solution. Following this development, the authors feel that any industrial wastewater containing biodegradable organic pollutants should be treatable with a high-rate anaerobic reactor system. In the meantime, the upflow sludgebed technology remains the working horse of anaerobic high-rate treatment. Only a few decades ago, reactor systems treating 10 tons of COD per day were regarded as considerable projects for the various contractors. At present, anaerobic sludge bed systems are treating more than 100 tons of COD per day, generating an electric energy potential of about $5 \mathrm{MW}$. To realize such projects technical developments should coincide with process engineering developments. In the end, the anaerobic high-rate reactor should sustain its lifetime, treating organically polluted wastewater, meanwhile converting the wasted organics in a valuable fuel.

\section{Conclusions}

An extensive assessment of 40 years anaerobic sludge bed technology for industrial wastewater treatment reveals the following:

- Anaerobic sludge bed treatment technology has been successfully applied to a wide spectrum of industrial wastewaters at full-scale as a consolidated technology.

- Anaerobic high-rate treatment technology is a cost-effective alternative providing energy saving, reduction in sludge production, operation at high organic loadings, compact footprint, and net energy production. These characteristics make anaerobic sludge bed technology feasible and sustainable for the treatment of virtually all organically polluted industrial wastewaters.

- Although the key mechanism of sludge bed technology is immobilization of microorganisms, various modern anaerobic high-rate reactors employ flocculent biomass which is retained in the system by advanced (gas-)liquid-sludge separation devices. In such reactors, sludge separation is brought about by in-built flotation units or advanced tilted plate settlers. Alternatively, membrane separation is employed, ensuring complete biomass retention without any necessity for granulation.

- The intensive research conducted on anaerobic sludge-bed systems using laboratory-scale reactor systems and which include molecular techniques and mathematical modeling resulted in the development of new reactor configurations, and 
applications of full-scale sludge bed systems, enabling the treatment of very complex wastewaters from chemical industries.

- As a waste-to-energy technology, high-rate anaerobic sludge (bed) systems enable renewable energy production, and nutrient rich effluent production for irrigation purposes in agricultural fields. Therefore, this technology significantly contributes to achieve the so-called "environmentally friendly" industrial production concept.

Open Access This article is distributed under the terms of the Creative Commons Attribution 4.0 International License (http:// creativecommons.org/licenses/by/4.0/), which permits unrestricted use, distribution, and reproduction in any medium, provided you give appropriate credit to the original author(s) and the source, provide a link to the Creative Commons license, and indicate if changes were made.

\section{References}

Abbasi T, Abbasi SA (2012) Formation and impact of granules in fostering clean energy production and wastewater treatment in upflow anaerobic sludge blanket (UASB) reactors. Renew Sustain Energy Rev 16(3):1696-1708

Agapakis CM, Boyle PM, Silver PA (2012) Natural strategies for the spatial optimization of metabolism in synthetic biology. Nat Chem Biol 8:527-535

Allison M, Grant S, Christian S, Wilson D (2013) Full-scale operating experience with USA-based ADI-AnMBR systems for food wastes. Proc Water Environ Fed 2013(10):5255-5270

Alphenaar PA (1994) Anaerobic granular sludge: characterization and factors affecting its functioning. PhD thesis, G. Lettinga (promotor), Department of Environmental Technology, Agricultural University, Wageningen, The Netherlands

Aydin AF, Ersahin ME, Dereli RK, Sarikaya HZ, Ozturk I (2010) Long-term anaerobic treatability studies on opium alkaloids industry effluents. J Environ Sci Health A Tox Hazard Subst Environ Eng 45(2):192-200

Bachmann A, Beard VL, McCarty PL (1985) Performancecharacteristics of the anaerobic baffled reactor. Water Res 19:99-106

Baloch MI, Akunna JC, Kierans M, Collier PJ (2008) Structural analysis of anaerobic granules in a phase separated reactor by electron microscopy. Bioresour Technol 99:922-929

Banu JR, Kaliappan S, Yeom IT (2007) Treatment of domestic wastewater using upflow anaerobic sludge blanket reactor. Int J Environ Sci Technol 4(3):363-370

Barber WP, Stuckey DC (1999) The use of the anaerobic baffled reactor $(\mathrm{ABR})$ for wastewater treatment: a review. Water Res 33:1559-1578

Barrera EL, Spanjers H, Solon K, Amerlinck Y, Nopens I, Dewulf J (2015) Modeling the anaerobic digestion of cane- molasses vinasse: extension of the anaerobic digestion model no. 1 (ADM1) with sulfate reduction for a very high strength and sulfate rich wastewater. Water Res 71:42-54

Batstone DJ, Keller J (2001) Variation of bulk properties of anaerobic granules with wastewater type. Water Res 35(7): 1723-1729

Batstone DJ, Keller J (2003) Industrial application of the IWA anaerobic digestion model no.1 (ADM1). Water Sci Technol 47(12):199-206

Batstone DJ, Keller J, Angelidaki I, Kalyuzhnyi SV, Pavlostathis SG, Rozzi A, Sanders WTM, Siegrist H, Vavilin VA (2002) Anaerobic Digestion Model No. 1, Scientific and Technical Report No. 13. IWA Publishing, London, UK

Batstone DJ, Keller J, Blackall LL (2004) The influence of substrate kinetics on the microbial community structure in granular anaerobic biomass. Water Res 38:1390-1404

Buswell AM (1957) Fundamentals of anaerobic treatment of organic wastes. Sew Ind Wastes 29:717-721

Buswell AM, Sollo FW (1948) The mechanism of the methane fermentation. Am Chem Soc J 70:1778

Buswell AM, Boruff CS, Wiesman CK (1932) Anaerobic stabilization of milk waste. Ind Eng Chem 24:1423-1425

Buyukkamaci N, Filibeli A (2002) Concentrated wastewater treatment studies using an anaerobic hybrid reactor. Process Biochem 38:771-775

Calderon K, Gonzales-Martinez A, Gomez-Silvan C, Osorio F, Rodelas B, Gonzales-Lopez J (2013) Archaeal diversity in biofilm technologies applied to treat urban and industrial wastewater: recent advances and future prospects. Int J Mol Sci 14(9):18572-18598

Chen Z, Hu D, Zhang Z, Ren N, Zhu H (2009) Modeling of twophase anaerobic process treating traditional Chinese medicine wastewater with the IWA anaerobic digestion model no. 1. Bioresour Technol 100:4623-4631

Christian S, Grant S, McCarty P, Wilson D, Mills D (2011) The first two years of full-scale anaerobic membrane bioreactor (AnMBR) operation treating high-strength industrial wastewater. Water Pract Technol 6(2)

De Zeeuw WJ (1982) Korrelslibbvorming Bij De Anaerobe Zuivering Van Destruktieafvalwater. Intern rapport. Vakgroep Waterzuivering, Landbouwhogeschool Wageningen, The Netherlands

De Zeeuw WJ (1987) Granular sludge in UASB-raectors. In: Granular anaerobic sludge; microbiology and technology workshop, Lunteren, The Netherlands, October 25-27

Dereli RK, Ersahin ME, Ozgun H, Ozturk I, Aydin AF (2010) Applicability of anaerobic digestion model no.1 (ADM1) for a specific industrial wastewater: opium alkaloid effluents. Chem Eng J 165(1):89-94

Dereli RK, Ersahin ME, Ozgun H, Ozturk I, Jeison D, van der Zee F, van Lier JB (2012) Potentials of anaerobic membrane bioreactors to overcome treatment limitations induced by industrial wastewaters. Bioresour Technol 122:160-170

Dolfing J (1987) Microbiological aspects of granular methanogenic sludge. Ph.D. thesis, Agricultural University, Wageningen, The Netherlands

Dos Santos AB, Cervantes FJ, van Lier JB (2007) Review paper on current technologies for decolourisation of textile wastewaters: perspectives for anaerobic biotechnology. Bioresour Technol 98(12):2369-2385 
Ehlinger F (1994) Anaerobic biological fluidized beds: operating experiences in France. In: 7th international symposium on anaerobic digestion, Cape Town, South Africa, January 23-27

Ersahin ME, Dereli RK, Insel G, Ozturk İ, Kinaci C (2007) Model based evaluation for the anaerobic treatment of corn processing wastewaters. Clean-Soil Air Water 35(6):576-581

Ersahin ME, Ozgun H, Dereli RK, Ozturk I (2011) Anaerobic treatment of industrial effluents: an overview of applications. In: Einschlag FSG (ed) Waste water-treatment and reutilization. InTech, India, pp 415-456

Ersahin ME, Ozgun H, Tao Y, van Lier JB (2014) Applicability of dynamic membrane technology in anaerobic membrane bioreactors. Water Res 48:420-429

Esparza Soto M, Solis Morelos C, Herna JJ (2011) Anaerobic treatment of a medium strength industrial wastewater at low-temperature and short hydraulic retention time: a pilotscale experience. Water Sci Technol 64(8):1629-1635

Fang HHP, Chui HK, Li YY (1994) Microbial structure and activity of UASB granules traeting different wastewaters. Water Sci Technol 30(12):87-96

Frijters CTMJ, Vos RH, Scheffer G, Mulder R (2006) Decolorizing and detoxifying textile wastewater, containing both soluble and insoluble dyes, in a full scale combined anaerobic/aerobic system. Water Res 40(6):1249-1257

Frijters CTMJ, Jorna T, Hesselink G, Kruit J, van Schaick D, van der Arend R (2014) Experiences with anaerobic treatment of fat-containing food waste liquids: two full scale studies with a novel anaerobic flotation reactor. Water Sci Technol 69(7):1386-1394

Fukuzaki S, Nishio N, Nagai S (1995) High rate performance and characterization of granular methanogenic sludges in upflow anaerobic sludge blanket reactors fed with various defined substrates. J Ferment Bioeng 79(4):354-359

Futselaar H, Rosink R, Smith G, Koens L (2013) The anaerobic MBR for sustainable industrial wastewater management. Desalin Water Treat 51:4-6

Grotenhuis JTC, Smit M, Plugge CM, Xu Y, Van Lammeren AAM, Stams AJM, Zehnder AJB (1991) Bacteriological composition and structure of granular sludge adapted to different substrates. Appl Environ Microbiol 57: 1942-1949

Grotenhuis JTC, Stams AJM, Zehnder AJB (1992) Hydrophobicity and electrophoretic mobility of anaerobic isolates from methanogenic granular sludge. Appl Environ Microbiol 58:1054-1056

Guiot SR, van den Berg L (1984) Performance and biomass retention of an upflow anaerobic reactor combining a sludge blanket and a filter. Biotechnol Lett 6(3):161-164

Guiot SR, Van den Berg L (1985) Performance of an upflow anaerobic reactor combining a sludge blanket and a filter treating sugar waste. Biotechnol Bioeng 27:800-806

Guiot SR, Pauss A, Costerton JW (1992) A structured model of the anaerobic granule consortium. Water Sci Technol 25(7):1-10

Guiot SR, Safi B, Frignon JC, Mercier P, Mullignan C, Tremblay R (1995) Performances of a full-scale novel multiplate anaerobic reactor treating cheese whey effluent. Biotechnol Bioeng 45:398-405
Habeeb SA, Latiff AABA, Daud ZB, Ahmad ZB (2011) A review on granules initiation and development inside UASB reactor and the main factors affecting granules formation process. Int J Energy Environ 2(2):311-320

Habets LHA, Knelissen JH (1985) Application of the UASB reactor for anaerobic treatment of paper and board mill effluent. Water Sci Technol 17(1):61-75

Habets LHA, Knelissen HJ (1997) In line biological water regeneration in a zero discharge recycle paper mill. Water Sci Technol 35(2-3):41-48

Habets LHA, Engelaar AJHH, Groeneveld N (1997) Anaerobic treatment of inuline effluent in an internal circulation reactor. Water Sci Technol 35(10):189-197

Heijnen SJ, Mulder A, Weltevrede R, Hols PH, van Leeuwen HLJM (1990) Large-scale anaerobic/aerobic treatment of complex industrial wastewater using immobilized biomass in fluidized bed and air-lift suspension reactors. Chem Eng Technol 13(1):202-208

Hinken L, Huber M, Weichgrebe D, Rosenwinkel KH (2014) Modified ADM1 for modelling an UASB reactor laboratory plant treating starch wastewater and synthetic substrate load tests. Water Res 64:82-93

Holst TC, Truc A, Pujol R (1997) Anaerobic fluidised beds: ten years of industrial experience. Water Sci Technol 36(6-7):415-422

Hulshoff Pol LW, Lettinga G (1986) Advanced reactor design, opeartion and economy. Water Sci Technol 18(12):99-108

Hulshoff Pol LW, de Zeeuw WJ, Velzeboer CTM, Lettinga G (1983) Granulation in UASB-reactors. Water Sci Technol 15(8/9):291-304

Hulshoff Pol LW, Heijnekamp K, Lettinga G (1987) The selection pressure as driving force behind the granulation of anaerobic sludge. In: Granular anaerobic sludge; microbiology and technology workshop, Lunteren, The Netherlands, October 25-27

Hulshoff Pol LW, de Castro Lopes SI, Lettinga G, Lens PNL (2004) Anaerobic sludge granulation. Water Res 38(6):1376-1389

Hwu C-S, Molenaar G, Garthoff J, van Lier JB, Lettinga G (1997a) Thermophilic high-rate anaerobic treatment of wastewater containing long-chain fatty acids: impact of reactor hydrodynamics. Biotechnol Lett 19:447-451

Hwu C-S, van Beek B, van Lier JB, Lettinga G (1997b) Thermophilic high-rate anaerobic treatment of wastewater containing long-chain fatty acids: effect of washed out biomass recirculation. Biotechnol Lett 19:453-456

Imhoff K (1916) Separate sludge digestion improves Imhoff tank operation by keeping sewage fresk. Eng Rec 74:101-102

Ismail SB, Gonzalez P, Jeison D, van Lier JB (2008) Effects of high salinity wastewater on methanogenic sludge bed systems. Water Sci Technol 58(10):1963-1970

Jeison D, van Lier JB (2007) Thermophilic treatment of acidified and partially acidified wastewater using an anaerobic submerged MBR: factors affecting long-term operational flux. Water Res 41:3868-3879

Jeison D, van Betuw W, van Lier JB (2008) Feasibility of anaerobic membrane bioreactors for the treatment of wastewaters with particulate organic matter. Sep Sci Technol 43:3417-3431 
Jeison D, Telkamp P, van Lier JB (2009) Thermophilic sidestream anaerobic membrane bioreactors: the shear rate dilemma. Water Environ Res 81(11):2372-2380

Kennedy KJ, Guiot SR (1986) Anaerobic upflow bed-filter-development and application. Water Sci Technol 18(12):71-86

Kleerebezem R, Macarie H (2003) Treating industrial wastewater: anaerobic digestion comes at age. Chem Eng 56-64

Kleerebezem R, Hulshoff Pol LW, Lettinga G (1999a) The role of benzoate in anaerobic degradation in terephthalate. Appl Environ Microbiol 65(3):1161-1167

Kleerebezem R, Hulshoff Pol LW, Lettinga G (1999b) Anaerobic degradation of phthalate isomers by methanogenic consortia. Appl Environ Microbiol 65(3):1152-1160

Lettinga G (2014) My anaerobic sustainability story. LeAF Publisher, Wageningen 2014, p 200. http://www.leafwageningen.nl/en/leaf.htm

Lettinga G, Hulshoff Pol LW (1991) UASB process design for various types of wastewater. Water Sci Technol 24(8):87-107

Lettinga G, van der Ben J, van der Sar J (1976) Anaerobe zuivering van het afvalwater van de bietsuikerindustrie. $\mathrm{H}_{2} \mathrm{O} 9: 38-43$

Lettinga G, van Velsen L, de Zeeuw W, Hobma SW (1979) The application of anaerobic digestion to industrial pollution traetment. In: 1st international symposium on anaerobic digestion, Cardiff, UK, September 17-21

Lettinga G, van Velsen AFM, Hobma SW, de Zeeuw W, Klapwijk A (1980) Use of the upflow sludge blanket (USB) reactor concept for biological wastewater treatment, especially for anaerobic treatment. Biotechnol Bioeng 22(4):699-734

Lettinga G, Zehnder AJB, Grotenhuis JTC, Hulshoff Pol LW (eds) (1987) In: GASMAT: international workshop on granular anaerobic sludge, microbiology and technology, Lunteren, The Netherlands, PUDOC, Wageningen, The Netherlands, 25-27 October, 1987

Li A, Sutton PM (1981) Dorr oliver anitron system, fluidized bed technology for methane production from dairy wastes. In: Whey products institute annual meeting, Chicago, USA

Lim SJ, Kim TH (2014) Applicability and trends of anaerobic granular sludge treatment processes. Biomass Bioenergy 60:189-202

Liu Y, Xu HL, Yang SF, Tay JH (2003) Mechanisms and models for anaerobic granulation in upflow anaerobic sludge blanket reactor. Water Res 37:661-673

Macarie H (1999) Overview of the application of anaerobic treatment to chemical and petrochemical wastewaters. Water Sci Technol 42(5-6):201-214

MacLeod FA, Guiot SR, Costerton JW (1990) Layered structure of bacterial aggregates produced in an upflow anaerobic sludge bed and filter reactor. Appl Environ Microbiol 56(6): 1598-1607

McCarty PL (2001) The development of anaerobic treatment and its future. Water Sci Technol 44(8):149-156

McHugh S, Carton M, Mahony T, O'Flaherty V (2003) Methanogenic population structure in a variety of anaerobic bioreactors. FEMS Microbiol Lett 219(2):297-304

Moletta R, Escoffier Y, Frédéric Ehlinger F, Coudert J-P, Leyris J-P (1994) On-line automatic control system for monitoring an anaerobic fluidized-bed reactor: response to organic overload. Water Sci Technol 30(12):11-20

Monroy O, Fama G, Meraz M, Montoya L, Macarie H (2000) Anaerobic digestion for wastewater treatment in Mexico: state of the technology. Water Res 34(6):1803-1816

Muñoz Sierra JD, Spanjers H, van Lier JB (2014) Biomass acclimatisation during start-up of AnMBR reactors treating saline phenolic wastewater. In: Proceedings of 11th Latin American Workshop and Symposium on Anaerobic Digestion. IWA conference, La Habana, Cuba, 25-28 November, 2014

Nnaji CC (2013) A review of the upflow anaerobic sludge blanket reactor. Desalin Water Treat 52:4122-4143

Ozgun H, Dereli RK, Ersahin ME, Kinaci C, Spanjers H, van Lier JB (2013) A review of anaerobic membrane bioreactors for municipal wastewater treatment: integration options, limitations and expectations. Sep Purif Technol 118:89-104

Ozgun H, Gimenez JB, Ersahin ME, Tao Y, Spanjers H, van Lier JB (2015) Impact of membrane addition for effluent extraction on the performance and sludge characteristics of upflow anaerobic sludge blanket reactors treating municipal wastewater. J Membr Sci 479:95-104

Patel GB, Sprott GD (1990) Methanosaeta concilii gen. nov., sp. nov. ("Methanothrix concilii") and Methanosaeta thermoacetophila nom. rev., comb. nov. Int J Syst Bacteriol 40:79-82

Pereboom JHF, Vereijken TLFM (1994) Methanogenic granule development in full scale internal circulation reactors. Water Sci Technol 30(8):9-21

Puñal A, Brauchi S, Reyes JG, Chamy R (2003) Dynamics of extracellular polymeric substances in UASB and EGSB reactors treating medium and low concentrated wastewaters. Water Sci Technol 48(6):41-49

Rajagopal R, Saady NMC, Torrijos M, Thanikal JV, Hung YT (2013) Sustainable agro-food industrial wastewater treatment using high rate anaerobic process. Water 5:292-311

Rajeshwari KV, Balakrishnan M, Kansal A, Lata K, Kishore VVN (2000) State-of-the-art of anaerobic digestion technology for industrial wastewater treatment. Renew Sustain Energy Rev 4:135-156

Ramakrishnan A, Gupta SK (2008) Effect of COD/NO ${ }_{3}-\mathrm{N}$ ratio on the performance of a hybrid UASB reactor treating phenolic wastewater. Desalination 232:128-138

Razo-Flores E, Macarie H, Morier F (2006) Application of biological treatment systems for chemical and petrochemical wastewaters. In: Cervantes FJ, Pavlostathis SP, van Haandel AC (eds) Advanced biological treatment processes for industrial wastewaters. IWA publishing, London

Rebac S, van Lier JB, Lens P, van Cappellen J, Vermeulen M, Stams AJM, Swinkels KThM, Lettinga G (1998) Psychrophilic $\left(6-15{ }^{\circ} \mathrm{C}\right)$ high rate anaerobic treatment of malting wastewater in a two-module expanded granular sludge bed system. Biotechnol Prog 14:856-864

Rebac S, van Lier JB, Lens PNL, Stams AJM, Dekkers F, Swinkels KTM, Lettinga G (1999) Psychrophilic anaerobic treatment of low strength wastewaters. Water Sci Technol 39(5):203-210

Rittmann BE, McCarty PL (2001) Environmental biotechnology: principles and applications. McGraw-Hill, New York 
Satoh H, Miura Y, Tsushima I, Okabe S (2007) Layered structure of bacterial and archaeal communities and their in situ activities in anaerobic granule. Appl Environ Microbiol 73(22):7300-7307

Schroepfer GJ, Fullen WJ, Johnson AS, Ziemke NR, Anderson JJ (1955) The anaerobic contact process as applied to packinghouse wastes. Sew Ind Wastes 27(4):460-486

Sekiguchi Y, Kamagata Y, Nakamura K, Ohashi A, Harada H (1999) Flourescence in situ hybridization using 16S rRNAtargeted oligonucleotides reveals localization of methanogens and selected uncultured bacteria in mesophilic and thermophilic granules. Appl Environ Microbiol 65(3):1280-1288

Seyfried CF (1988) Reprints verfahrenstechnik abwasserreiningung, GVC-Diskussionstagung, Baden-Baden, Germany, October 17-19

Song M, Shin SG, Hwang S (2010) Methanogenic population dynamics assessed by real-time quantitative PCR in sludge granule in upflow anaerobic sludge blanket treating swine wastewater. Bioresour Technol 101(1, Supplement):S23S28

Speece RE (1996) Anaerobic biotechnology for industrial wastewaters. Archae Press, USA

Strydom JP, Britz TJ, Mostert JF (1997) Two-phase anaerobic digestion of three different dairy effluents using a hybrid bioreactor. Water SA 23(2):151-156

Subramanyam R (2013) Physicochemical and morphological characteristics of granular sludge in upflow anaerobic sludge blanket reactors. Environ Eng Sci 30(5):201-212

Sung S, Dague RR (1995) Laboratory studies on the anaerobic sequencing batch reactor. Water Environ Res 67(3):294-301

Tagawa T, Takahashi H, Sekiguchi Y, Ohashi A, Harada H (2002) Pilot-plant study on anaerobic treatment of a lipidand protein-rich food industrial wastewater by a thermophilic multi-staged UASB reactor. Water Sci Technol 45(10):225-230

van Lier JB (2008) High-rate anaerobic wastewater treatment: diversifying from end-of-the-pipe treatment to resourceoriented techniques. Water Sci Technol 57(8):1137-1148

van Lier JB, Vashi A, van der Lubbe J, Heffernan B (2010) Anaerobic sewage treatment using UASB reactors: engineering and operational aspects. In: Fang HHP (ed) Environmental anaerobic technology; applications and new developments. World Scientific, Imperial College Press, London, pp 59-89 Chapter 4. ISBN 978-1-84816-542-7

Van Lier JB, Boncz MA (2002) Controlling calcium precipitation in an integrated anaerobic aerobic treatment system of a 'zero-discharge' paper mill. Water Sci Technol 45(10):341-348

van Lier JB, Boersma F, Debets MMWH, Lettinga G (1994) High rate thermophilic wastewater treatment in compartmentalized upflow reactors. Water Sci Technol 30(12):251-261

van Lier JB, van der Zee F, Tan FP, Rebac S, Kleerebezem R (2001) Advances in high-rate anaerobic treatment: staging of reactor systems. Water Sci Technol 44(8):15-25

van Lier JB, Mahmoud N, Zeeman G (2008) Anaerobic biological wastewater treatment. In: Henze M, van Loosdrecht
MCM, Ekama GA, Brdjamovic D (eds) Biological wastewater treatment: principles, modeling and design. IWA Publishing, London

van Loosdrecht MCM, de Kreuk MK, Heijnen JJ (2002) Aerobic granular sludge formation. In: J.B. van Lier, M. Lexmond, H. de Vos (eds) Proceedings of "Granulation and Autoimmobilisation Processes in Wastewater Treatment", farewell seminar Hulshoff Pol, June 28, Wageningen, The Netherlands

Vanderhaegen B, Ysebaert E, Favere K, Van Wambeke M, Peeters T, Panic V, Vandenlangenbergh V, Verstraete W (1992) Acidogenesis in relation to in-reactor granule yield. Water Sci Technol 25:75-81

Vellinga SHJ, Hack PJFM, van der Vlugt AJ (1986) New type "high rate" anaerobic reactor; first experience on semitechnical scale with a revolutionary and high loaded anaerobic system. In: Anaerobic treatment: a grown-up technology, aquatech water treatment conference, Amsterdam, The Netherlands, September 15-19

Wiegant WM, de Man AWA (1986) Granulation of biomass inthermophilic anaerobic sludge blanket reactors traeting acidified wastewaters. Biotechnol Bioeng 28:718-727

Wirtz RA, Dague RR (1996) Enhancement of granulation and start-up in the anaerobic sequencing batch reactor. Water Environ Res 68(5):883-892

Wu WM, Hickey RF, Zeikus JG (1991) Characterisation of metabolic performance of methanogenic granules treating brewrey wastewater: role of sulfate-reducing bacteria. Appl Environ Microbiol 57:3438-3449

Yang J, Spanjers H, Jeison D, van Lier JB (2013) Impact of $\mathrm{Na}^{+}$ on biological wastewater treatment and the potential of anaerobic membrane bioreactors: a review. Crit Rev Environ Sci Technol 43(24):2722-2746

Young JC (1991) Factors affecting the design and performance of upflow anaerobic filters. Water Sci Technol 24(8):133-155

Young JC, McCarty PL (1969) The anaerobic filter for waste treatment. J Water Pollut Control Fed 41:160-173

Young JC, Yang BS (1989) Design considerations for full-scale anaerobic filters. J Water Pollut Control Fed 61(9):1576-1587

Zaher U, Moussa MS, Widyatmika IN, van Der Steen P, Gijzen HJ, Vanrolleghem PA (2006) Modelling anaerobic digestion acclimatisation to a biodegradable toxicant: application to cyanide. Water Sci Technol 54(4):129-137

Zhu G, Zou R, Jha AK, Huang X, Liu L, Liu C (2015) Recent developments and future perspectives of anaerobic baffled bioreactor for wastewater treatment and energy recovery. Crit Rev Environ Sci Technol 45(12):1243-1276

Zoutberg GR, De Been P (1997) The Biobed ${ }^{\circledR}$ EGSB (expanded granular sludge bed) system covers shortcomings of the upflow anaerobic sludge blanket reactor in the chemical industry. Water Sci Technol 35(10):183-188

Zoutberg GR, Frankin R (1996) Anaerobic treatment of chemical and brewery waste water with a new type of anaerobic reactor; the biobed ${ }^{\circledR}$ EGSB reactor. Water Sci Technol 34(5-6):375-381 